\title{
Effects of eight weeks' continuous treatment with oral ranitidine and cimetidine on gastric acid secretion, pepsin secretion, and fasting serum gastrin
}

\author{
R MOHAMMED, R J HOLDEN, J B HEARNS, B M McKIBBEN, \\ $K$ D BUCHANAN, and G P CREAN \\ From the Gastro-Intestinal Centre, Southern General Hospital, Glasgow, and University Department of \\ Medicine, Queen's University, Belfast
}

SUMMARY Gastric acid secretion, pepsin secretion, and fasting serum gastrin levels were measured in 23 patients with duodenal ulcer disease, divided into three groups which received either cimetidine $800 \mathrm{mg}$ daily, cimetidine $1600 \mathrm{mg}$ daily, or ranitidine hydrochloride $300 \mathrm{mg}$ daily for eight weeks. Pentagastrin tests were carried out at intervals both before and after treatment. Each dose of cimetidine reduced acid secretion to $42 \%$ of control one week after starting therapy. Ranitidine reduced acid secretion to $33 \%$ of the pretreatment value. Acid secretion remained suppressed to these levels throughout treatment with each drug. Acid secretion returned to pretreatment levels in all patients one week after treatment and remained normal until the end of the study. Both drugs reduced pepsin, which fell to $64 \%$ and $61 \%$ $(\mathrm{p}<0.01)$ after $800 \mathrm{mg}$ and $1600 \mathrm{mg}$ cimetidine respectively and to $65 \%(\mathrm{p}<0.005)$ with ranitidine after one week's treatment. Pepsin secretion remained at this reduced level in both cimetidine groups till the end of treatment. Pepsin levels fell to $50 \%$ at two weeks of therapy with ranitidine but stabilised at this level till the end of therapy. Cimetidine withdrawal was followed by a return towards pretreatment levels of pepsin secretion; but secretion remained significantly depressed $(p<0.05)$ to the end of the study period. In the ranitidine-treated patients pepsin output returned to normal after drug withdrawal. Fasting gastrin levels rose during treatment with both drugs but failed to reach significant levels. After withdrawal of treatment fasting serum gastrin levels returned to normal in all three groups of patients.

The gastric acid inhibitory properties of cimetidine are well known. ${ }^{12}$ Ranitidine hydrochloride is a new histamine $\mathrm{H}_{2}$-receptor antagonist which is structurally different from cimetidine and is reported to be several times more potent on a molar basis. ${ }^{34}$ Although the half life of these drugs is short, ${ }^{56}$ each is capable of reducing gastric $\mathrm{pH}$ to low levels for long periods over 24 hours during treatment with usual therapeutic doses. ${ }^{78}$ Substantial suppression of acid secretion could theoretically result in sustained hypergastrinaemia and subsequent acid hypersecretion.

Gastrin induces parietal cell hyperplasia in experimental animals ${ }^{9}$ and very large doses of metiamide,

Received for publication 26 March 1982 a histamine $\mathrm{H}_{2}$-receptor antagonist, have been reported to produce parietal cell hyperplasia and gastric hypersecretion in rats. ${ }^{10}$ Cimetidine, in very large doses $(150 \mathrm{mg} / \mathrm{kg}-950 \mathrm{mg} / \mathrm{kg})$ for up to two years, appears to induce an increase in the surface area of the stomach, with consequential increases in the volume (mass) of the fundic mucosa, and in the total parietal cell population. These effects are relatively trivial and are dissimilar to the effects induced by gastrin: the mechanism is unknown. ${ }^{11}$

The present investigation was carried out in an attempt to discover whether such effects could be identified in subjects with duodenal ulcer disease treated for a two month period with two different doses of cimetidine and with the likely therapeutic dose of ranitidine. 
Methods

PATIENTS

Twenty-three patients with duodenal ulcer disease participated in the study, each giving informed consent. Six patients were treated with $800 \mathrm{mg}$ cimetidine daily (group 1); six were treated with $1600 \mathrm{mg}$ cimetidine daily (group 2); and 11 received $300 \mathrm{mg}$ ranitidine daily (group 3 ). Cimetidine was prescribed in doses $200 \mathrm{mg}$ and $400 \mathrm{mg}$ to be taken after meals and before retiring to bed and ranitidine was prescribed in a dose of $150 \mathrm{mg}$ at breakfast and with the evening meal.

After the injection of pentagastrin $6 \mu \mathrm{g} / \mathrm{kg}$ intramuscularly four 15 minute collections of gastric secretions were made (MAO). These gastric secretion studies were performed before treatment began (control test) and on day 7, 14, 28, and 56 of treatment (designated treatment weeks $1,2,4$, and 8 ) and on day 7, 14, and 28 after treatment with cimetidine was stopped (post-treatment weeks 1, 2, and 4) and on day 7, 14, 28, and 56 after ranitidine was stopped (post-treatment weeks $1,2,4$, and 8). On the days that secretion tests were performed during the treatment period, the first dose of cimetidine and ranitidine was taken 60 minutes before gastric aspiration started.

From each collection of gastric juice $5 \mathrm{ml}$ were titrated for hydrogen ion concentration against $0 \cdot 1$ $\mathrm{N}$ sodium hydroxide and acid secretion expressed as the output of $\mathrm{HCl}$ (concn $\times$ volume) in the hour after pentagastrin. A $10 \mathrm{ml}$ aliquot was deep frozen at $-18^{\circ} \mathrm{C}$ for subsequent pepsin analysis by Piper's method. ${ }^{12}$ The results were expressed as milligrammes of sigma pepsin standard ( $1 \mathrm{mg}=450 \mathrm{IU})$ in the hour after pentagastrin.

In patients treated with ranitidine a single blood sample was taken 90 minutes after the ingestion of the morning dose, heparinised and stored at $-20^{\circ} \mathrm{C}$ for subsequent plasma ranitidine estimation.

Blood was also withdrawn for fasting serum gastrin levels on each test occasion before gastric aspiration was begun. These blood samples were stored at $-20^{\circ} \mathrm{C}$ until transported to Belfast for gastrin estimation by radioimmunoassay. The assay was performed using antibody R98, which showed cross-reactivity $(1: 10000)$ on a weight basis with cholecystokinin-pancreozymin and no crossreactivity with other gastrointestinal peptides. The assay has a lower limit of detection of 5 picograms per ml. ${ }^{13}$

Statistical analysis was carried out using analysis of variance and Page's $L$ test and differences between weeks in the experiment assessed by the Wilcoxon signed rank test.

\section{Results}

ACID SECRETION (Figs 1 and 2)

In all three groups there was a highly significant fall in acid output after one week of treatment as compared with control values $(p<0.001)$, the acid falling to $42 \%$ of control in both cimetidine groups and to $33 \%$ in the ranitidine group. The acid output remained suppressed at this level throughout the remainder of the treatment period. After drug withdrawal acid output returned towards normal in all three groups, the acid output reaching $83 \%$ and $72 \%$ in the cimetidine groups and $93 \%$ in the ranitidine group. The acid output values after treatment did not differ significantly from control values in any group studied.

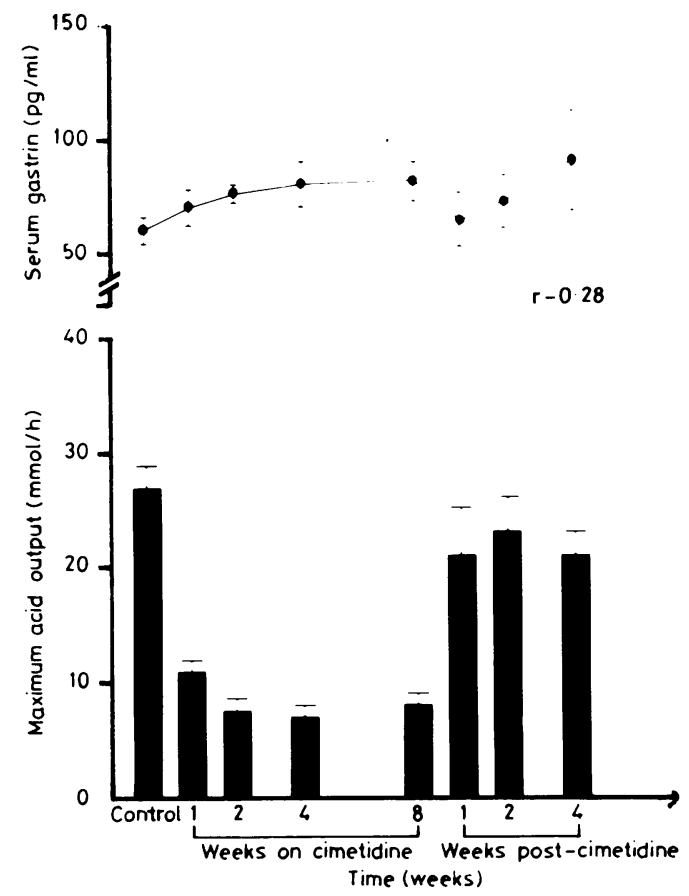

Fig. 1 Serum gastrin levels $(\mathrm{pg} / \mathrm{ml})$ and acid output (mmol/h)-ordinate. Control week, weeks during, and weeks after therapy-abscissa. Points show the mean $\pm S E M$. Results combined for group I $(800 \mathrm{mg}$ cimetidine) and group II (1600 mg cimetidine) daily $(n=12)$. Last dose taken one hour before test. $P$ values: the value at each test during the treatment period was significantly lower than the control test $(p<0.01)$. There were no significant differences among the values found during the treatment period, the control test compared with any post-treatment test, nor among any of the post-treatment tests. 

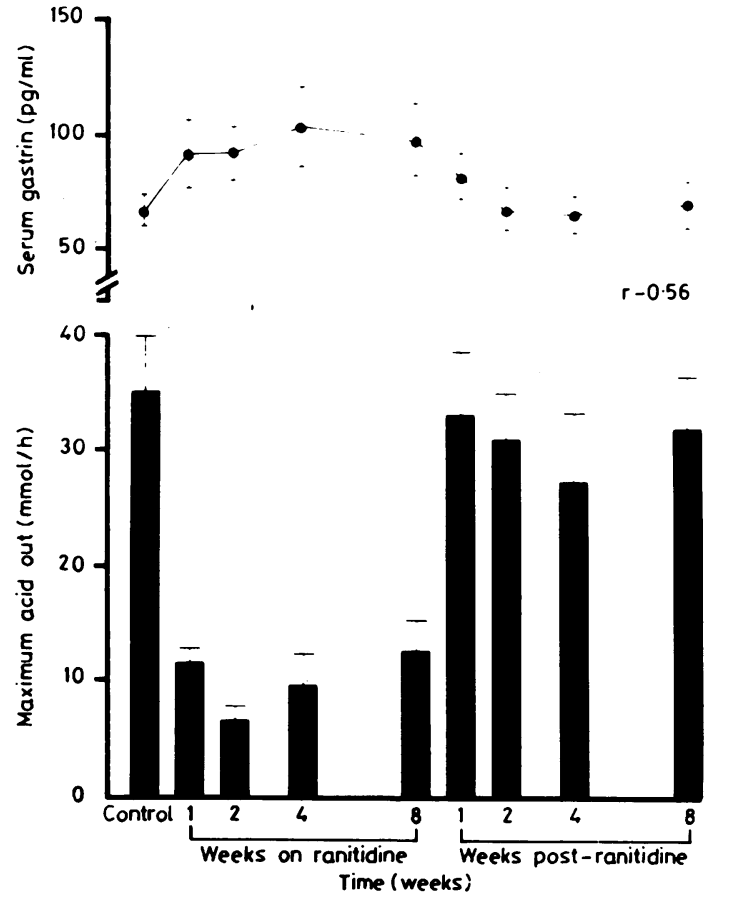

Fig. 2 Serum gastrin levels $(\mathrm{pg} / \mathrm{ml})$ and acid output (mmol/h) -ordinate. Control week, weeks during, and weeks after therapy - abscissa. Points show the mean \pm SEM. Group III (300 mg ranitidine) daily $(n=11)$. Last dose taken one hour before test. $P$ values: the value at each test during the treatment period was significantly lower than the control test $(p<0.001)$. There were no significant differences among the values found during the treatment period, the control test compared with any post-treatment test, nor among any of the post-treatment tests.

PEPSIN SECRETION (Fig. 3)

In the two cimetidine-treated groups there was a significant fall in pepsin output after one week of treatment $(\mathrm{p}<0.01)$ to $64 \%$ and $61 \%$ in group 1 and group 2 respectively. Pepsin output remained at this level for the rest of the treatment period, so that none of the values obtained during treatment differed significantly from each other, although all values were significantly less than the control output $(\mathrm{p}<0 \cdot 05)$. After cimetidine withdrawal pepsin output had not returned completely to normal even at the four weeks' test. The mean pepsin output at week 1 after drug withdrawal was only $60 \%$ of the pretreatment level $(p<0 \cdot 05)$. None of the posttreatment values differed significantly from any other but were all significantly lower than control $(\mathrm{p}<0 \cdot 05)$.

In the ranitidine-treated patients the pepsin output fell significantly to $65 \%$ of the control value after one week of treatment $(p<0 \cdot 005)$. There was a further significant fall to $50 \%$ of the control level at week 2 of treatment; the values stabilising thereafter at this level for the remainder of the treatment period. After ranitidine withdrawal, unlike the cimetidine-treated patients, there was a prompt rise in pepsin output to levels not significantly different from that of control.

FASTING SERUM GASTRIN (groups 1, 2, and 3)

The changes in serum gastrin are shown in Figs 1 and 2 . The values during treatment with cimetidine show a slight rise in both groups; these changes did not, however, attain statistical significance. Similarly, in patients given ranitidine there was a rise in fasting serum gastrin levels during treatment which also failed to reach statistical significance.

After withdrawal of cimetidine and ranitidine, fasting serum gastrin levels fell towards normal in all three groups. No correlation was found to exist between serum gastrin and acid secretion before, during, or after therapy with either drug.

\section{PLASMA DRUG LEVELS}

The mean ranitidine levels during the treatment period (taken 90 minutes after the oral dose of the drug) were $399 \mathrm{ng} / \mathrm{ml}( \pm 58), 467 \mathrm{ng} / \mathrm{ml}( \pm 53), 466$ $\mathrm{ng} / \mathrm{ml}( \pm 61)$, and $287 \mathrm{ng} / \mathrm{ml}( \pm 73)$ at weeks $1,2,4$, and 8 of treatment respectively.

\section{Discussion}

The acid output of the stomach obtained after stimulation by $6 \mu \mathrm{g} / \mathrm{kg}$ pentagastrin intramuscularly provides a reproducible test of the maximal secretory capacity of the stomach, which is indistinguishable from the response obtained with 40 $\mu \mathrm{g} / \mathrm{kg}$ histamine. ${ }^{14}{ }^{15}$ The simplicity and reproducibility of the test makes it an ideal method for monitoring drug effects on gastric acid secretion.

Acid output of the stomach was reduced by approximately $60 \%$ after one week of treatment with $800 \mathrm{mg}$ or $1600 \mathrm{mg}$ cimetidine daily and by $70 \%$ after one week of treatment with ranitidine. Acid secretion was maintained at this reduced level throughout treatment, with no suggestion that acid secretion escaped from the effect of the drugs during treatment nor any suggestion of a progressive decrease in secretion with continuing therapy as had been previously suggested from preliminary studies. ${ }^{16}$ The reduction in acid secretion observed at one week of continuous therapy is of the same magnitude as that seen after a single dose of cimetidine. ${ }^{1}$ Statistical analysis suggested that the daily dose of $1600 \mathrm{mg}$ exerted only a slightly greater 


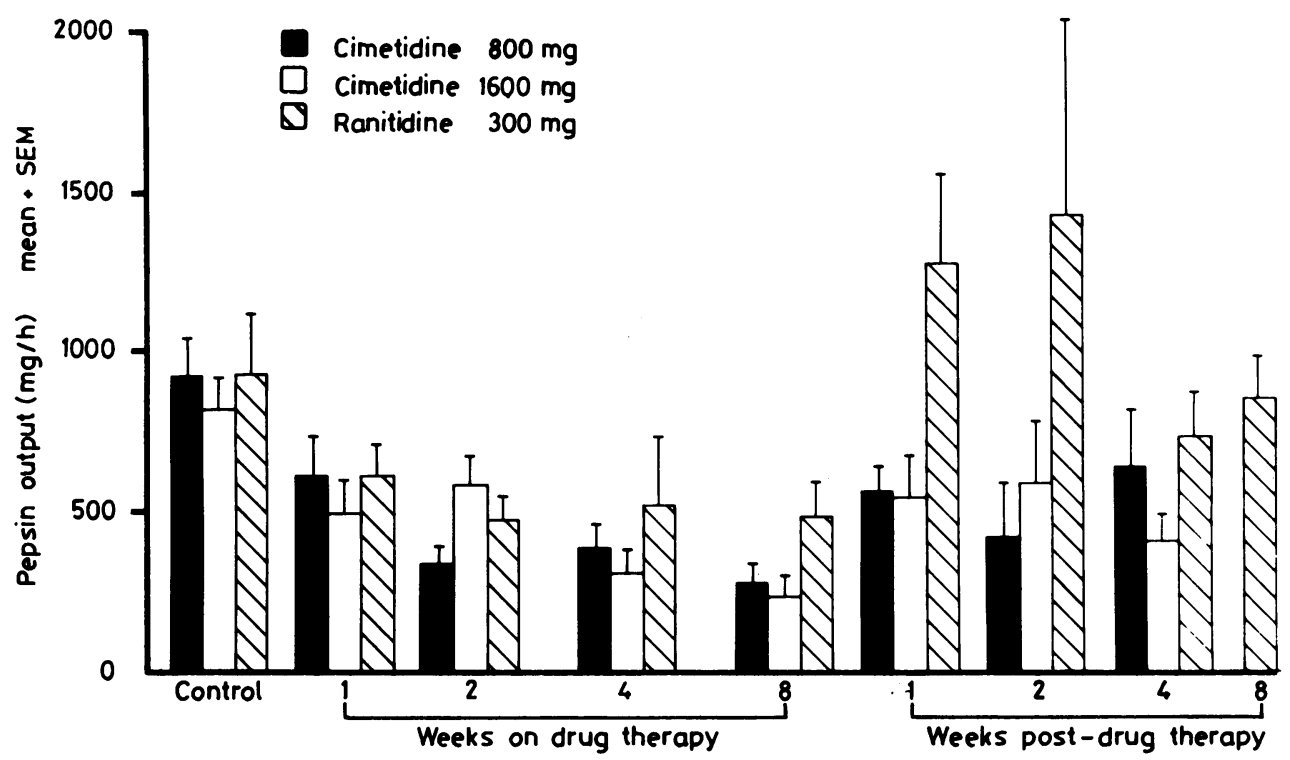

Fig. 3 Pepsin output $(\mathrm{mg} / \mathrm{h})$-ordinate. Control week, weeks during, and weeks after therapy - abscissa. Points show mean $\pm S E M$ (groups I, II, III). P values: (groups I and II). The value at each test during the treatment period was significantly lower than the control test for both groups $(p<0.01)$. There were no significant differences among the values found during the treatment period in either group nor among any of the post-treatment tests. The post-treatment tests were significantly lower than the control value in both groups $(p<0.05)$. (Group III). The value at each test during the treatment period was significantly lower than the control test $(p<0.005)$. The values for tests at weeks 2,4 , and 8 of treatment were significantly lower than the value at week $1(p<0.001)$. There were no significant differences among the post-treatment test values nor between the control test compared with any post-treatment test.

effect on acid secretion than $800 \mathrm{mg}$ cimetidine daily (p 0.05). There was neither suggestion of 'rebound' hypersecretion nor of failure of acid secretion to return after therapy with either drug. The results are in keeping with previous studies which showed no change from control values of basal and pentagastrin stimulated secretion tested after four and eight weeks of treatment, ${ }^{17}{ }^{16}$ but differ from a further study in which acid output was stimulated by histamine infusion. ${ }^{18}$ This showed a $23 \%$ reduction in stimulated acid secretion after three months' treatment with cimetidine, but acid secretion was tested at variable intervals after treatment ended. The difference between this study and the present results could be due to any of several factors, including the differences in the stimulant, the duration of treatment, the timing of tests after drug withdrawal, or a combination of these factors. Rebound hypersecretion, however, has never been described.

Although pepsin output was reduced during treatment with cimetidine and ranitidine the effects of pepsin secretion were much less pronounced, a feature which has been noted in previous studies. ${ }^{1} 19$
Moreover, while pepsin output tended to increase after cimetidine withdrawal, it had not returned to pretreatment levels at any time up to four weeks after therapy. This was in contrast with patients treated with ranitidine in whom there was an apparent hypersecretion of pepsin after drug withdrawal, although none of the post-treatment values differed significantly from control. It has been suggested that pepsin secretion falls with duodenal ulcer healing, ${ }^{20}$ but with pepsin levels returning promptly to normal after ranitidine treatment this cannot be the complete answer for the effect observed in patients given cimetidine.

Fasting serum gastrin levels showed no significant changes during cimetidine or ranitidine therapy in this study, which is in keeping with other studies. ${ }^{21-}$ ${ }^{23}$ In themselves, these results are not surprising because, while histamine $\mathrm{H}_{2}$-receptor antagonists clearly reduce gastric acidity, mere alkalinisation of the stomach may not stimulate gastrin release. ${ }^{24}$ The alkaline antrum, however, may be more sensitive to stimulation by other factors, particularly food, which accounts for the disproportinate rise in serum gastrin obtained by food stimulation during 
treatment with metiamide or cimetidine. ${ }^{25} 26$ In other studies, however, no changes in the serum gastrin response to food have been obtained, ${ }^{1822}$ differences which have probably depended upon whether or not antral $\mathrm{pH}$ was controlled during the experiment. In addition, fasting gastrin levels largely comprise high molecular weight species which have dubious biological significance, and have relatively low amounts of G34 and G17, the more biologically active molecules. Response to feeding would have given a more exact assessment of the gastrin status. ${ }^{28}$

The levels of plasma ranitidine obtained in this study were found to be well within the therapeutic range $^{27}$ suggesting that $300 \mathrm{mg}$ oral ranitidine daily is likely to be adequate for the treatment of duodenal ulceration.

It would appear that $300 \mathrm{mg}$ ranitidine hydrochloride, in twice daily dose, has a very similar effect to that of $800 \mathrm{mg}$ or $1600 \mathrm{mg}$ cimetidine in terms of acid and pepsin secretion in patients with duodenal ulcer disease without affecting gastrin levels. This suggests that the two drugs are likely to be very similar in their clinical effect.

We thank Dr J Bem and Dr R England of Glaxo Group Research Ltd, for the supply of drugs and Mrs Mary McDougall for secretarial assistance. Thanks are also due to the Medical Illustration Department of Stobhill General Hospital, Glasgow, and to the Staff of the Gastro-Intestinal Centre, Southern General Hospital, for performing the gastric secretion tests.

\section{References}

1 Burland WL, Duncan WAM, Hesselbo T, Mills JG, Sharp PC, Haggie SJ, Wyllie JH. Pharmacological evaluation of cimetidine. A new histamine $\mathrm{H}_{2}$-receptor antagonist in healthy man. Br J Clin Pharmacol 1975; 2: 481-6.

2 Pounder RE, Williams JG, Milton-Thompson GJ, Misiewicz JJ. Effect of cimetidine on 24 hour intragastric acidity in normal subjects. Gut 1976; 17: 131-8.

3 Bradshaw J, Brittain RT, Clitherow JW, Daly MJ, Jack D, Price BJ, Stables R. Ranitidine (AH 19065): a new potent, selective histamine $\mathrm{H}_{2}$ receptor antagonist. $\mathrm{Br} \mathrm{J}$ Pharmacol 1979; 66: 464.

4 Domschke W, Lux S, Domschke S, Demling L. New $\mathrm{H}_{2}$-receptor antagonist inhibits human gastric acid secretion more strongly than cimetidine. Gut $1979 ; 20$ : A450-1.

5 Griffiths R, Lee RM, Taylor BC. Kinetics of cimetidine in man and experimental animals. In: Burland WL,
Simkins MA, eds. Cimetidine: proceedings of the second international symposium on histamine $\mathrm{H}_{2^{-}}$ receptor antagonists. Amsterdam: Excerpta Medica, 1977: 38-51.

6 Woodings EP, Dixon GT, Harrison C, Carey P, Richards DA. Ranitidine. A new $\mathrm{H}_{2}$-receptor antagonist. Gut 1980; 21: 187-91.

7 Pounder RE, Williams JG, Milton-Thompson GJ, Misiewicz JJ. 24 Hour control of intra gastric acidity by cimetidine in duodenal ulcer patients. Lancet 1975; 2: 1069-72.

8 Damman HG, Kather H, Augustin HJ, Simon B. Investigations on the length of action of ranitidine. Dtsch Med Wochenschr 1980; 105: 603-5.

9 Crean GP, Marshall MW, Rumsey RD. Parietal cell hyperplasia induced by the administration of pentagastrin. Gastroenterology 1969; 57: 147-55.

10 Halter F, Witzel L. Increased acid secretion after sustained metiamide medication in the rat. Gastroenterology 1977; 72: A6/816.

11 Crean GP, Daniel D, Leslie GB, Bates C. The effects of prolonged administration of large doses of cimetidine on the gastric mucosa of rats. In: Wastell C, Lance P, eds. Cimetidine: The Westminster Hospital Symposium. Edinburgh: Churchill Livingstone, 1978: 191-205.

12 Piper BW. The estimation of peptic activity in gastric juice using radio-iodinated serum albumin as substrate. Gastroenterology 1960; 38: 616.

13 Ardill JES. The measurement of gastrin by radioimmunoassay. Queen's University, Belfast: Thesis, 1973.

14 Kay AW. Effect of large doses of histamine on gastric secretion of $\mathrm{HCl}$. Br Med J 1953; 2: 77-80.

15 Multi-centre pilot study. Pentagastrin as stimulant of maximal gastric acid response in man. Lancet 1967; 1: 291-5.

16 Crean GP, Holden RJ, Mackenzie I, Hearns JB. The effect of six weeks administration of cimetidine on gastric acid secretion. In: Burland WL, Simkins MA, eds. Cimetidine: proceedings of the second international symposium on histamine $\mathrm{H}_{2}$-receptor antagonists. Amsterdam: Excerpta Medica, 1977: 122-3.

17 Barbezat GO, Bank S. Basal acid output response to cimetidine in man. In: Burland WL, Simkins MA, eds. Cimetidine: proceedings of the second international symposium on histamine $\mathrm{H}_{2}$-receptor antagonists. Amsterdam: Excerpta Medica, 1977: 110-9.

18 Spence RW, Celestin LR, McCormick DA. Effect on gastric acid output of prolonged treatment with cimetidine in duodenal ulcer patients. Gut 1976; 17: 831.

19 Peden NR, Saunders JHB, Wormsley KG. Inhibition of pentagastrin-stimulated and nocturnal gastric secretion by ranitidine. Lancet 1979; 1: 690-2.

20 Elder JB, Smith IS. Gastric acid output, pepsin output and lean body mass in normals and duodenal ulcer subjects. Lancet 1975; 1: 1000-3.

21 Bank S, Barbezat GO, Vinik AI, Halter F, Helman CA. Cimetidine and serum gastrin levels in man. In: Burland WL, Simkins MA, eds. Cimetidine: proceedings of the second international symposium on 
histamine $\mathrm{H}_{2}$-receptor antagonists. Amsterdam: Excerpta Medica, 1977: 155-62.

22 Spence RW, Celestin LR, McCormick DA, Owens CJ. The effect of three months treatment with cimetidine on basal and 'Oxo' stimulated serum gastrin. In: Burland WL, Simkins MA, eds. Cimetidine: proceedings of the second international symposium on histamine $\mathrm{H}_{2}$-receptor antagonists. Amsterdam: Excerpta Medica, 1977: 163-74.

23 Konturek SJ, Obtulowicz W, Kwiecien N, Sito E, Mikos E, Oleksy J. Comparison of ranitidine and cimetidine in the inhibition of histamine, sham-feeding and meal-induced gastric secretion in duodenal ulcer patients. Gut 1980; 21: 181-6.

24 Higgs RH, Smyth RD, Castell DO. Gastric alkalinisation effect on lower oesophageal sphincter pressure and serum gastrin. $N$ Engl J Med 1974; 291: 486-90.

25 Barbezat GO, Grant B, Bank S, Vinik AI. The effect of histamine $\mathbf{H}_{2}$-receptor blockade with metiamide on serum gastrin levels in man. Gut 1975; 16: 186-7.

26 Richardson CT, Walsh JH, Hicks MI. The effect of cimetidine, a new histamine $\mathbf{H}_{2}$-receptor antagonist on meal stimulated acid secretion, serum gastrin and gastric emptying in patients with duodenal ulcer. Gastroenterology 1976; 71: 19-23.

27 Peden NR, Richards DA, Saunders JHB, Wormsley KG. Pharmacologically effective plasma concentrations of ranitidine. Lancet 1979; 2: 199-200.

28 Dockray GJ, Taylor IL. Heptadecapeptide gastrin: measurement in blood by specific radioimmunoassay. Gastroenterology 1976; 71: 971-7. 